\title{
PEDIATRIC PARATESTICULAR RHABDOMYOSARCOMA
}

\author{
Amir HALILBAŠIĆ, Nešad HOTIĆ, Edin HUSARIĆ
}

Department of pediatrics

University Clinical Center Tuzla

Tuzla, Bosnia and Herzegovina

A 13-year old boy was referred with a left sided testicular swelling that had been noticed over the past 2 months. On examination a large tumor was noticed in the left hemiscrotum (Panel A). After admission, radical orchiectomy with high cord ligation and wide excision of surrounding soft tissue of the inguinal canal and scrotum were performed (Panel B). The tumor was $13 \times 7 \times 8$ centimeters in size (Panel C). Histopathologic exam confirmed the diagnosis of a spindle-cell subtype of paratesticular embryonal rhabdomyosarcoma, and the resection was complete. CT and MRI scans did not reveal enlarged lymphnodes in the retroperitoneum, pelvis and there were no local or distant metastases. The tumor was staged as IRS Group I (fully resected localized disease). Rhabdomyosarcoma is a highly malignant, small blue cell tumor characterized by muscle differentiation. It is a rare malignancy in children and adolescents. Prognosis is related to initial tumor resectability, as well as the staging of the disease based on tumor invasiveness, tumor bulk, nodal disease and metastases. Multimodal therapy, with surgery, chemotherapy, and radiotherapy provides the patient with an excellent longterm prognosis. With modern treatment, more than $70 \%$ of children and adolescents with this disease are cured.

Key words: Rhabdomyosarcoma - Paratesticular - Orchiectomy.

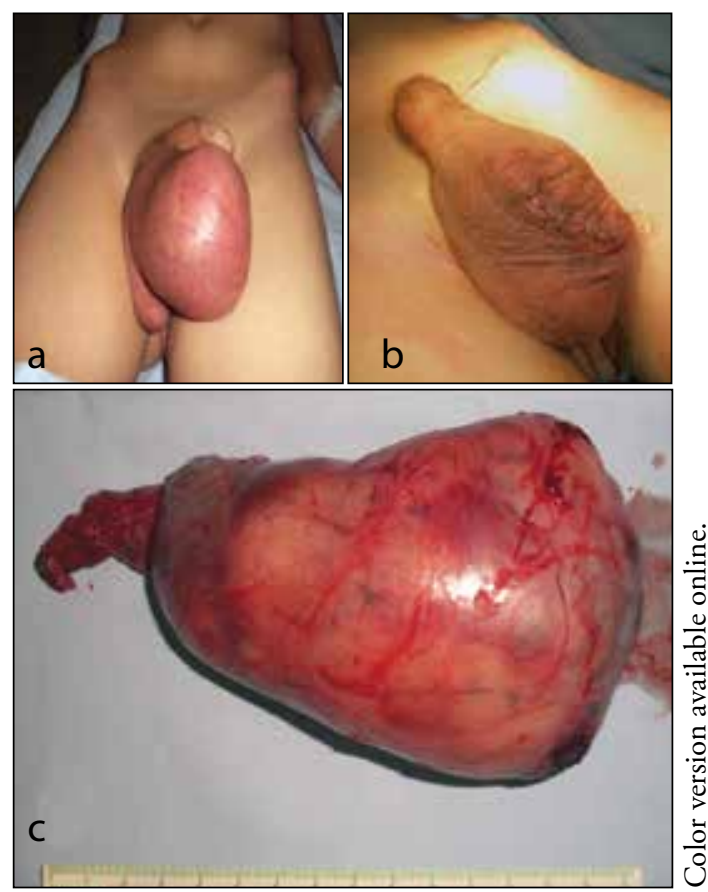

Authors' contributions: Conception and design: $\mathrm{AH}$, $\mathrm{EH}$; Acquisition, analysis and interpretation of data: $\mathrm{NH}$; Drafting the manuscript: AH, EH.; Revising it critically for important intellectual content: $\mathrm{AH}, \mathrm{NH}$.

Conflict of interest: The authors declare that they have no conflict of interest.

Corresponding author:

Amir Halilbašić

Department of pediatrics

University Clinical Center Tuzla

75000 Tuzla

Bosnia and Herzegovina

hamir@bih.net.ba

Tel.: + 38761259 016; Fax.: + 38735250474

Received: December 24, 2012; Accepted: April 1, 2013

Copyright (C) 2013 by University Clinical Center

Tuzla. E-mail for permission to publish:

paediatricstoday@ukctuzla.ba 